\title{
PROBLEM BENTUK DAN MAKNA PADA KUMPULAN PUISI DWIBAHASA GURIT BANDHA DONYA-PUISI KEKAYAAN DUNIA
}

\author{
M. Shoim Anwar \\ Program Studi Pendidikan Bahasa Indonesia, Fakultas Ilmu Sosial dan Humaniora \\ Universitas PGRI Adi Buana Surabaya \\ shoimanwar@unipasby.ac.id
}

\begin{abstract}
ABSTRAK: Tujuan peneltian ini adalah menginterpretasi, menganalisis, dan mendeskripsikan problem bentuk dan makna kumpulan puisi dwibahasa Gurit Bandha Donya-Puisi Kekayaan Dunia dalam kerangka pendekatan kualitatif. Kumpulan puisi ini memiliki makna beragam sesuai dengan kecenderungan tematik para penyairnya. Puisi yang berbahasa Jawa ditulis lebih awal, kemudian diterjemahkan oleh penyair ke bahasa Indonesia. Puisi berbahasa Jawa terasa lebih padat dibanding hasil terjemahannya. Ada kecenderungan dalam menerjemahkan penyair menambahkan kata-kata atau konsep tertentu sehingga bentuknya menjadi lebih panjang. Dalam kasus tertentu ada pula yang terjadi pengurangan konsep sehingga makna puisi menjadi berbeda.

Umumnya dalam penerjemahkan puisi penyair masih terikat pada penerjemahan kata perkata. Idiom-idiom dalam puisi belum dialihkan ke idiom bahasa lain yang maknanaya mirip. Kesenjangan idiom inilah yang menjadi permasalahan dalam penerjemahan puisi dari bahasa Jawa ke bahasa Indonesia.
\end{abstract}

Kata kunci: puisi, dwibahasa. penerjemahan, idiom

ABSTRACT: The purpose of this research is to interpret, analyze, ande describe the problem of form and meaning of the bilingual collection of Gurit Bandha Donya-Puisi Kekayaan Dunia within the framework of the qualitative approach. This collection of poems has, has various meanings according to thematic tendencies of the poets. Poetry in Javanese was written earlier by the poet, then translated by the poet into Indonesian. Javanese poetry feels denser than the translation. There is a tendency in translating poets to add certain words or concepts so that the form become longer. In certain cases there is also a reduction in the concept so that the meaning of the poem becomes different.

Generally, in the translating poetry, poets are still tied to the translation of the words. Idioms in the poetry have not been transferred to othe language idioms with similar meanings. This idiom gap is a problem in translating poetry from Javanese to Indonesian.

Keywods: poetry, bilingual, translation, idiom

\section{PENDAHULUAN}

Kumpulan puisi (guritan) Gurit Bandha Donya merupakan karya dwibahasa, yaitu berbahasa Jawa dan berbahasa Indonesia yang ditulis oleh 
sembilan penyair, yaitu Aming Aminoedhin, Widodo Basuki, R.Djoko Parakosa, Deny Tri Aryanti, Trinil, Suharmono K., R.Giryadi, Razuno Kaori, dan Suparto Brata. Setiap puisi ditulis secara berurutan dalam bahasa Jawa dan bahasa Indonesia. Pada sampul depan tertulis judul dalam bahasa Jawa dengan ukuran lebih besar, sedangkan judul Puisi Kekayaan Dunia tertulis di bawahnya dengan ukuran lebih kecil. Posisi dan ukuran huruf pada judul buku tersebut mengisyaratkan bahwa puisi yang berbahasa Jawa (guritan) lebih ditonjolkan. Buku ini memang diterbitkan oleh Paguyuban Pengarang Sastra Surabaya (PPSJS) dan Forum Sastra Bersama Surabaya (FSBS) tahun 2014.

Buku ini memiliki nilai lebih karena disusun secara dwibahasa. Bagi pembaca, yang mungkin kurang memahami idiom-idiom bahasa Jawa, akan sangat terbantu karena puisi yang ada juga diterjemahkan ke bahasa Indonesia. Mereka yang tidak memahami bahasa Jawa pun dapat langsung membaca puisi yang berbahasa Indonesia. Segmen pembaca kumpulan puisi ini seharusnya lebih luas.

Penerjemah puisi-puisi dalam Gurit Bandha Donya adalah para penyairnya sendiri. Mereka juga terbiasa menulis dalam bahasa Indonesia. Nilai lebihnya, seharusnya, adalah dapat menghindari kesenjangan makna dari puisi yang diterjemahkan tersebut. Para penyair mengetahui dengan pasti makna puisi yang ditulisnya sehingga kontrol semantisnya juga terjaga. Meski begitu, seperti telah disinggung oleh Suharmono K. pada kata pengantar buku ini, menerjemahkan puisi ke bahasa lain memang tidak mudah walau dilakukan penyairnya sendiri. Secara teknis, inilah tantangan terbesar para penyair. Antara bentuk dan isi yang harus disampaikan dalam dua bahasa adalah pertarungan dua dunia.

Puisi adalah salah satu genre sastra yang terdiri atas lapis bentuk dan lapis isi.

Lapis bentuk sebuah puisi antara lain ditampakkan melalui pilihan kata, baris, bait, rima, majas atau gaya bahasa. tipogragi atau wujud visualnya, serta hal-hal lain yang kasat mata. Sementara itu lapis isi pada puisi adalah makna yang terkandung di dalamnya. Makna puisi dapat dipahami dari berbagai sisi. Lapis bentuk dan lapis isi keduanya sama-sama penting.

Makna puisi, bagi seorang pembaca atau penerjemah, antara lain dapat dipahami melalui pola semantik, bahasa kias, serta pengungkapan yang tidak langsung (Luxemburg, 1986:185-192). Makna puisi dapat bersifat eksplisit atau denotatif, yakni makna sesuai dengan yang tersurat. Makna ini bersifat permukaan atau harafiah. Pada sisi lain, puisi dapat bermakna implisit atau konotatif, yakni makna tersirat yang sengaja disamarkan atau disembunyikan oleh penyairnya. Makna puisi dibangun secara kompleks. Unit-unit makna atau arti puisi itu dapat dilihat dari penggunaan kata, kelompok kata, kalimat, serta berbagai unit yang dibangun dari kalimat yang bersifat jamak (Sayuti, 2002:352).

Kejelian dalam menerjemahkan sebuah puisi dari sebuah bahasa ke bahasa lain harus benar-benar diterapkan. Puisi bukan sekadar masalah bentuk, namun isi atau makna yang terkandung di dalamnya harus tetap tersampaikan dengan baik. 
Puisi, atau karya sastra pada umumnya, dalam pandangan Skilleas (2001:2-16) dapat dipersandingkan dengan teks filsafat karena memiliki hubungan "filsafat sebagai sastra" dan "sastra sebagaI filsafat" sehingga melahirkan disiplin "filsafat sastra". Kedekatan antara filsafat dan sastra ini pula yang melahirkan pendekatan filsafat dalam studi sastra (Hogan, 2000). Karena karya sastra dapat dipersandingkan dengan filsafat, penerjemahannya pun harus memperhitungkan sisi filosofi di dalamnya.

Menerjemahkan sebuah puisi pasti berhadapan dengan berbagai kode sebagai konvensi dalam melahirkan makna. Pembaca, yang nantinya juga bertindak sebagai penerjemah, harus benar-benar paham terhadap kode bahasa, kode budaya, dan kode sastra (Teeuw, 1983:12-38) agar dapat menghasilkan karya terjemahan yang baik, minimal tidak menyimpang terlalu jauh dari gagasan yang disampaikan penulis aslinya. Pentingnya pemahaman terhadap kode juga disampaikan oleh Eco (2016:81-83 ) dalam teori semiotik yang mengharuskan seorang pembaca, penerjemah, atau penerima pesan dalam memahami makna teks, yang di dalamnya terkandung kode denotatif dan kode konotatif. Hal yang juga perlu disadari oleh penerjemah, bertolak dari teori Riffaterre, bahasa dalam karya sastra merupakan sistem tanda tingkat kedua, setelah sistem tanda tingkat pertama yang melekat pada bahasa itu sendri (Setiawan, 2016:3)

Banyak kasus penerjemahan karya sastra, khususnya puisi, yang masih bersifat formal atau secara setia didasarkan makna/semantik dalam kamus secara apa adanya. Secara teoretis, penerjemahan dapat dilakukan dengan mengubah metafor atau majas yang terdapat dalam bahasa sumber ke bahasa sasaran, asalkan makna yang dikandung tidak menyimpang terlalu jauh (Supardi, 2017:404).

Problem penerjemahan sebuah puisi muncul karena antara bentuk dan isi dalam puisi sama-sama penting. Bentuk puisi adalah sarana yang terkait langsung dengan estetika bahasa, sedangkan isi adalah muatan atau pesan yang terkandung di dalamnya. Penerjemah harus memperjuangkan keselarasan bentuk dan isinya. Samsuri, sorang ahli bahasa, menyatakan bahwa ada karya sastra yang tidak mungkin diterjemahkan, tidak saja karena demikian individualnya, akan tetapi juga karena aspek-aspek bahasanya dieksploitasikan sedemikian sehingga bahasa lain tidak mungkin dipakai untuk mengodekan estetikanya. Sebuah contoh yang baik telah dilakukan oleh Burton Raffel (Samsuri, 1983:5) dalam menerjemahkan puisi Chairil Anwar "Nisan" ke bahasa Inggris.

\section{Nisan}

Untuk nenekanda

Bukan kematian benar menusuk kalbu

Keridlaanmu menerima segala tiba

Tak kutahu setinggi itu atas debu

dan duka maha tuan bertahta

\section{Gravestone}




\section{For my Grandfather}

It's not death,no, that stabs at my heart

But your willingness to go.

Nor do I know how high

You are, now supreme over dust, over sorrow.

Terjemah puisi "Nisan" ke bahasa Inggris di atas sangat baik karena antara bentuk dan isi dapat dipertahankan. Rima silang atau persamaan bunyi pada tiap akhir baris dengan pola a-b-a-b dapat dipertahankan dari sisi bunyi. Yang sedikit mengganggu adalah kata "nenekanda" diterjemahkan menjadi "my Grandfather", bukan "my Grandmother".

Kasus penerjemahan terjadi pada kidungan (pantun) ludruk Jawa Timur yang diterjemahkan oleh Supriyanto dari bahasa Jawa ke bahasa Indonesia. Kidungan dari Cak Durasim itu berbunyi:

Pagupon omahe dara,

Melok Nippon tambah sengsara.

Dalam tiga buah buku yang ditulis oleh Supriyanto, kidungan itu diterjemahkan berbeda. Tampak bahwa sang penerjemah belum menentukan sikap atas terjemahan kata "dara" (burung merpati).

Pagupon rumah merpati,

Ikut Nippon tambah sengsara

$(1986: 112)$

Pagupon rumah burung dara

Ikut Nippon tambah sengsara

Pagupon, rumah burung merpati/dara

Ikut Nippon, tambah sengsara

(2012:3)

Setelah mencermati beberapa kasus dan konsep terjemahan, masalah yang muncul dalam kajian ini adalah bagaimanakah keberadaan antara bentuk dan makna puisi dwibahasa (bahasa Jawa dan bahasa Indonesia) dalam kumpulan Gurit Bandha Donya? Kajian ini akan membahas problem makna dan terjemahan dari puisis-puisi dwibahasa pada kumpulan tersebut.

\section{METODE}

Kanjian ini menggunakan pendekatan kualitatif-deskripsikan. Sumber datanya adalah kumpulan puisi dwibahasa (Jawa-Indonesia) yang berjudul Gurit Bandha Donya-Puisi Kekayaan Dunia yang memuat puisi-puisi karya Aming Aminoedhin, Widodo Basuki, R.Djoko Parakosa, Deny Tri Aryanti, Trinil, Suharmono K., R.Giryadi, Razuno Kaori, dan Suparto Brata. Kumpulan puisi itu diterbitkan oleh Paguyuban Pengarang Sastra Jawa Surabaya (PPSJS) tahun 2014.

Konsep atau teori yang digunakan terkait dengan bentuk dan makna puisi serta teknik penerjemahan karya sastra. Data dikumpulkan melalui kepustakaan. 
Analisis dilakukan secara dialektik, bertolak dari teks puisi yang dimaknai secara timbal balik dari keseluruhan ke sebagian dan dari sebagian ke keseluruhan. Dari sana diperoleh makna dari teks ke konteks dan sebaliknya.

\section{HASIL DAN PEMBAHASAN \\ Puisi Aming Aminoedhin}

Judul buku Gurit Banda Donya diambil dari puisi Aming Aminoedhin. Kelompok kata "bandha donya" dalam konteks puisi tersebut adalah harta, harta benda, atau kekayaan. Idiom lain yang mungkin dapat dipersandingkan adalah "donya brana". Pesan yang terkandung dalam puisi Aming adalah kita harus menghindarkan diri dari sikap "kedonyan" alias gila harta atau materialistik. Konotasi "bandha donya" dalam konteks tersebut adalah negatif. Dalam terjemahan bahasa Indonesia puisi tersebut menjadi Puisi Kekayaan Dunia. Judul terakhir inilah yang tampaknya aneh, konteks konotasinya berubah menjadi positif karena ada kesan "puisi sebagai kekayaan dunia".

Aming Aminoedhin "beruntung" karena secara alfabetis namanya dimulai dengan huruf A sehingga karyanya terpacak pada urutan awal. Masih menjadi ciri khasnya, Aming Aminoedhin adalah penyair (penggurit) yang memiliki kepekaan sosial yang tinggi. Sajak-sajak Aming umumnya sangat kontekstual dengan situasi sekitar. Salah satu penyebab Aming produktif dalam menulis sajak adalah responnya yang cepat dalam melihat fenomena sosial. Awal tahun 1980-an, sejak saya mengenalnya di Surabaya, seperti tak ada objek yang terlewatkan di mata Aming. Tampaknya apa pun bisa menjadi materi sajak buatnya. Lekuk-lekuk Surabaya mulai dari bemo, aspal, asap, knalpot, lampu-lampu neon, papan iklan, bus kota, terminal, plaza, orang belanja, penumpang kendaraan, cuaca panas, keringat, pohonan, tanam, para pegawai, anggota dewan, birokrasi, korupsi, pelacur, warung kopi, laut, ombak, angin, nelayan, layang-layang, dan masih banyak lagi yang dapat disajakkan olehnya. Citra atau imaji visual begitu kuat pada saja-sajak Aming.

Sajak-sajak Aming tentu ada yang merupakan renungan pribadi. Unsur religi atau spiritualitas menjadi menguat pada beberapa tahun terakhir. Spiritualitas dihadirkan tetap sebagai reaksi dari kehidupan sosial. Dalam konteks inilah sajaksajak Aming memiliki nuansa "dakwah", di samping protes sosial yang juga memiliki muatan mengajak ke arah kebaikan. Dalam kumpulan ini Aming juga bicara demikian. Masalah rebutan jabatan, tingkah perempuan yang tidak semestinya, korupsi, sikap pragmatis dan materialistis menjadi tema yang dikedepankan oleh Aming. Maka, sebagai peneduh agar kehidupan tidak semakin runyam, Aming menggaris bawahi pesannya dalam sajak "Dununge Seneng":

Dununge seneng iku

Ana atimu dhewe-dhewe

Seneng tetulung liyan 
Seneng aweh ilmu marang liyan

Seneng bisa gawe gumuyune liyan

Karya-karya Aming bukanlah "puisi kamar" yang sulit dipahami. Karyanya cocok dibacakan di panggung, bahkan dapat lintas usia, mulai anak hingga orang tua. Dia tipe penyair "berkeliaran" sehingga banyak karyanya yang merupakan hasil perjalan ke berbagai tempat, setipe dengan penyair Tengsoe Tjahjono yang produktif.

\section{Puisi R. Djoko Prakosa}

Kesan umum yang tidak dapat dihindari adalah para penyair, dalam menerjemahkan karyanya, berusaha menjelaskan makna puisi tersebut ke dalam bahasa Indonesia seperti teknik parafrase. Ada rasa kekhawatiran pembaca tidak mengerti sehingga perlu dideskripsikan lebih gamblang. Efek yang muncul adalah puisi menjadi prosais. Salah satu contoh adalah puisi R. Djoko Prakosa berikut.

\section{YEN KOWE MATI}

diajeng siti nurani..

lamuna jeneng sira arep mati..mati ya...sing tenanan

ing uripmu ... aja sambat....

lara..mlarat, lan wedi sekarat

ngelingana urip

mu sakdrema den uripi

hiyooooo....

tate..tate urube

latu sauruban kentir

semribite angin sore

\section{BILA KAU MATI}

dinda siti nurani..

seandainya engkau menginginkan kematian sejati

ya..... engkau harus memiliki kesungguhan

Ego harus sungguh-sungguh mati....

dalam kebenaran hidup......janganlah engkau menjadi merana,

sakit...merasa melarat, dan kemudian takut memasuki sakaratul maut

ingatlah bahwa hidup kita,

Ego yang kita puja hanya dihidupi sekedarNya

hiyoooo.............

tate-tate(1) api menyala hanyalah sebuah letupan

hidup, nyala apipun segera tertiup

semerbak angin di senja nanti 
Ciri paling menonjol puisi-puisi Djoko Prakosa, seperti juga tampak pada kumpulan guritannya Ngeluk Duwung Nggelung Gunung (2014) adalah pemakaian tanda baca secara berurutan. Hampir semua puisi Djoko terdapat pemakaian tanda baca titik secara memanjang atau berurutan (.........). Pengucapan demikian merupakan pengaruh ekspresi bahasa lisan yang dikodekan. Hal tersebut juga terkait efek musikalitas yang harus dipanjangkan ketika puisi diperlakukan sebagai tembang yang dilantunkan dengan irama tertentu hingga terdengar mendayu. Katakata yang tertulis pada puisi Djoko pun kerap diberi penekan panjang: hiyooooo....., puuuiiiiiiiiihhhhhhh....!!!!!!!, byurrrrrrr .

Pemakaian tanda baca maupun huruf secara berurutan dapat ditekan agar tidak terkesan boros dan gagap. Pemakaiannya secara berlebihan memberi kesan kotor pada wajah teks. Tidak ada pengaruh makna secara signifikan pada pemakaian tanda baca atau huruf secara berurutan.

Dari sisi isi, Djoko Prakosa termasuk penyair yang sangat terbuka terhadap tema puisi. Dalam Gurit Bandha Donya Djoko bicara tentang rasa ketuhanan, kematian yang harus diterima dengan lapang, janji-janji politik yang tak ditepati, hidup yang penuh godaan dan rebutan, serta rasa cinta yang ikhlas. Pada buku yang lain, nuansa asmara yang romantik juga bertebaran pada karya-karyanya. Puisi Djoko kadang tampak sangat "menep", mengendap hingga muncul nuansa tua dan "sumeleh", tapi di sisi lain, ketika bicara soal asmara, muncul pula kesan muda dan penuh gairah. Latar dan nuansanya sangat agraris pedesaan. Citra dan roh Jawa pada puisi-puisi Djoko sangat kuat.

\section{Puisi Trinil}

Rasa kekhawatiran penyair kalau puisinya tidak dimengerti pembaca memang kerap terjadi. Pada kasus lain, dalam puisi "Singa Ijen" karya Trinil, penerjemah perlu menambahkan penujuk jenis kelamin "betina" meski pada puisi aslinya tidak ada.

\section{Aku singa}

Sing wis kadhung nasaki carang

Kasil mlebu alas sangar

Dilulu daging seger anyar

Nggarahi kemecer kudu ngganyang.

Tapi endi kewan-kewan liyane?

Gak onok singa lanang?

Pada terjemahan bahasa Indonesia baris pertama muncul "Aku singa betina". Tanpa diberi "betina" konteks sajak tersebut sudah cukup jelas bahwa si "aku" adalah singa betina karena pada baris ketujuh sudah tertulis "Gak onok singa lanang?" sebagai pihak yang dicari.

Aku singa betina

Yang tlah terlanjur menembus belukar

Berhasil kuak rimba raya 
Ditantang sekerat daging segar merona

Menggiurkanku untuk memangsanya.

Tapi mana satwa yang lain?

Tak adakah singa jantan?

Beberapa puisi karya Trinil juga kerap diberi catatan di bagian akhir yang dapat berfungsi membantu pemaknaannya, seperti: Gawanku teka pengungsene mbakyuku korbane Lapindo, Guritan ketanggor babon brahi, guritan gawe "ngudang" bojoku sing nggantheng dhewe. Trinil adalah satu-satunya penyair yang konsisten untuk memakai bahasa Jawa dialek Surabaya sebagai media ekspresi. Dari sembilan penyair dalam Gurit Bandha Donya, delapan orang berasal dari latar belakang budaya mataraman (kulonan). Mungkin mereka yang berlatar belakang budaya sama dengan Trinil akan senang dengan puisi-puisinya dan dapat menikmati, seperti halnya menonton pertunjukan ludruk. Sifat terbuka budaya arek menjadikan puisi Trinil terasa merakyat dan gamblang, diberi catatan penjelas pula. Karya-karya Trinil merepresentasikan estetika puitik Surabaya.

Aku nggawe ukara dadi gurit cik gak sampek njerit

La iya, ibukku dikrokoti penyakit

Bapakku dikuras wong klebon dhemit

Cangkeme lamis bengesan clorit

Donyane bapakku entek korat-karit

Mlebu wetenge dhemit ngganthenge amit-amit

Ngaku putu macak prajurit

Tibake asu mlayu kecerit-cerit

Oalah Gusti, paringana berkat kuwat slamet

Sinten mawon sing ikhlas nglakoni orip niki!

\section{Puisi Razuno Kaori}

Salah satu puisi Trinil adalah "Lompur Megilan" yang merupakan reaksi langsung atas melubernya lumpur Lapindo di Sidoarjo, nada protesnya kuat khas Surabaya. Ini sangat berbeda dengan puisi "Tugu Kuning Ing Desa Siring” yang ditulis Razuno Kaori. Meski mengambil tema yang sama, Razuno menulis dengan gaya mataraman sesuai dengan budaya bahasa yang membesarkannya (Kediri). Puisi Razuno juga enak dibaca karena permainan rima yang mendukung makna. Puisi Razuno lainnya adalah "Kampung Jembarku, Surabaya". Kedua puisi Razuno bicara tentang masa lalu yang hilang, nostalgik. Puisi kedua menyiratkan bangga pada perkembangan kota Surabaya, tapi merasa rindu pada situasi masa lalu yang hilang ditelan zaman. Ini pemikiran yang khas penikmat budaya. Masa lalu dan masa kini bersitegang secara romantik. Seperti menjilat pacar pertama, tetap terasa walau waktu telah meninggalkannya.

Budi Palopo juga sering menerapkan estetika puitik Surabaya dalam guritannya, tetapi gaya mataramannya masih lebih dominan. Sayang sekali 
karyanya tidak masuk di buku ini. Bedanya dengan Trinil, Budi Palopo sering memberi penjelasan panjang lebar sebelum puisinya dibacakan di panggung. Bagi audiens kadang hal tersebut malah mengganggu, kurang percaya pada kemampuan puisi sebagai media komunikasi. Menjelaskan makna puisi sendiri secara berlebih justru dapat memiskinkan puisi itu. Dalam hal inilah "menerangkan" malah berubah jadi "menggelapkan".

\section{Puisi Deny Tri Aryanti}

Dalam penerjemahan memang tidak setiap kata harus diterjemahkan. Kecermatan terhadap makna sajak menjadi acuan penting agar tidak terjadi distorsi makna. Sebagai contoh, terjemahan puisi "Tembang Pendhapa Jawa (III)" oleh Deny Tri Aryanti penting untuk disimak.

\section{TEMBANG PENDHAPA JAWA ( III )}

Aku isih ora bisa ngenteni tekane prau ngawruh wengi lan ngresepi arti sawijine tetembangan sanadyan tan ana rasa nutupi sakdawane dalan getih sajeroning daging lan pikiran kalunta

\section{LAGU PENDHAPA JAWA ( III )}

Aku tak sanggup menunggu datangnya perahu mengeja malam dan meresapi arti sebuah nyanyian meski tak ada rasa yang menyumbat aliran darah yang tenggelam dalam raga dan pikiran sia

Kata "isih" pada baris pertama tidak muncul pada terjemahan bahasa Indonesia. Meski satu kata, kata "isih" (masih) menjadi sangat penting karena menyiratkan makna kejadian atau sesuatu yang sudah pernah terjadi, jamak, serta ada aspek waktu yang berulang. "Aku isih ora bisa ngenteni tekane prau" intensitasnya berbeda dengan "Aku tak sanggup menunggu datangnya perahu". Yang pertama menunjuk pada ketidaksanggupan meski sudah berulang kali dicoba. Sedangkan yang kedua hanya sekali itu saja terjadi.

Kata "isih" menjadi aspek waktu sangat penting pada puisi-puisi Deny dalam buku ini. Dari enam puisi yang ada, lima di antaranya terkandung kata “isih" yang sekaligus menjadi roh puisi. Puisi-puisi Deny menyiratkan pertarungan dua dunia, antara masa lalu dan masa kini. Masa lalu terlalu kuat dan melekat dalam rentang sejarah kehidupan si aku lirik. Terdapat subjek si engkau yang disembunyikan. Engkau tidak selalu menunjuk pada subjek yang sama. Hubungan antara si aku dengan si engkau, masa lalu dan kini, menjadi romantika yang penuh warna. Karya-karya Deny memberi kesan susana batin yang kuat, meski kadang meremang karena ada subjek di balik bayang. Di sana terbangun sikap nostalgik yang kuat, keteguhan, kesetiaan, tapi kadang menyayat. 


\section{YA GENE...}

Ya gene....

aku isih isa ngejrah jenengmu...

kanthi getih kang mili saka ati

Senadyan ora sesambungan maneh

lelakon iki bakal dadi kembang setaman e uripku.

nganti tumekaning pati

\section{NGANTI.....}

kaya dene kangenku kang datan bisa di emban dening langit semono uga pangrasaku kang isih waton marang sliramu aja dadi pikir nganti sajeroning impen merga tresna iki bakal tak gawa nganti tutuping yuswa..

\section{Puisi Giryadi}

Senada dengan karya-karya Deny Tri Aryanti, puisi-puisi R.Giryadi mengungkapkan susana hati yang melodramatik. Nada "nguda rasa" ditampilkan melalui simbol-simbol alam yang sekaligus dipakai judul puisi: Kopi, Wilangan, Kali, Pedhut, Mendung. Pada lima judul puisi yang ada Giryadi mengurai ada sesuatu hilang dalam hidup. Pahit dan getirnya kehidupan, keadilan yang diselewengkan, hati yang diselimuti rasa sunyi, kecewa karena dikhianati hingga muncul keinginan untuk menghadap sang pencipta dengan tenang.

Roh puisi Giryadi adalah rasa sunyi yang menyayat hati, mirip puisi-puisi Amir Hamzah dalam kumpulan Nyanyi Sunyi. Rasa sunyi dan sakit pada Giryadi, seperti pada puisi "Mendung", tidak semata-mata problem asmara, tapi yang lebih mendalam adalah: ini sakit hatinya orang yang bersembunyi / di balik mendung yang bergulungan / penghalang cahaya-Mu. Pada catatan di akhir puisi "Kali" memberi penunjuk yang jelas bahwa ekspresi yang tertuang adalah untuk "nglawan banjir bandhange ati". Terdapat subjek yang terbelah pada puisi Giryadi. Terjadi ketidakberdayaan yang ingin dilepaskan, tapi di satu sisi sang subjek malah berlari menyembunyikan ketidakberdayaan itu.

Jika pada puisi Deny ada subjek yang disembunyikan dan tidak terkesan bermusuhan, pada karya Giryadi subjek lain yang disembunyikan itu berhadapan secara berlawanan seperti tertuang pada puisi "Pedhut":

pedhut iku kaya kaya mbabar zaman ja mbejuja

rikala pangimpen iku kaukir sajembare mega

lan kowe cidra ing ati cidra ing janji. ngubur kasatyan ing njero bumi ngobong katresnan kang tinandur ing jaja. pedhut lelimengan alelimeng kaya nyingitake wadi, wadining cidra krana dunya brana. 


\section{Puisi Widodo Basuki}

Widodo Basuki adalah tipe penyair perenung yang kuat. Enam puisi dalam kumpulan ini Widodo mengetengahkan tema renungan terkait hubungan antara alam-manusia-Sang Pencipta: gerimis adalah awal sumber kehidupan, hidup haruslah sabar dan pasrah, selalu memuji kesucian Tuhan, rasa ikhlas harus ditegakkan walau terasa sulit, bertobat adalah jalan terbaik, dan kata-kata yang terucap akan menjadi kesaksian di alam lain sehingga harus dibarengi dengan rasa yakin yakin. Fenomena sangkan paraning dumadi, dari mana dan mau ke mana hidup ini, menjadi roh puisi Widodo.

Dalam kumpulan puisinya Bocah Cilik Diuber Srengege (2011) hampir semua puisi Widodo juga diarahkan ke dimensi religi. Widodo adalah penyair yang kuat dan matang dalam menggali persoalan hidup. Ada semacam kredo yang dipegang Widodo, kata-kata memiliki dimensi yang tak terhingga. Dalam puisi "Melesat Bareng Ukara" Widodo berujar.

ukara iki lumesat

menyang langit!

nepusi laladan-laladan sing tan kinira

tan kajangka sadurunge

jalaran ukara ngungkuli nalar

Ibarat lukisan, puisi Widodo memiliki nunsa yang sama dengan lukisan Amang Rahmat, nglangut ke langit dari segala objek yang digarap. Karena Widodo juga seorang pelukis, kemungkina dia juga menyukai lukisan Amang Rahman. Beberapa sketsa atau gambar dalam kumpulan Bocah Cilik Diuber Srengege, juga pada lukisan-lukisan kanvasnya yang pernah dipamerkan, tampak bahwa Widodo Basuki memiliki kecenderungan estetik seperti lukisan Amang Rahman.

\section{Puisi Suharmono K.}

Suharmono K. adalah penyair yang telah mapan dalam jagat kepenyairan Jawa. Dalam buku Gurit Bandha Donya dia termasuk tokoh senior yang memiliki jam terbang paling tinggi.Terdapat lima puisi karya Suharmomo K. yang disertakan. Beberapa puisi tersebut juga termuat dalam buku kumpulan puisinya Kidung Lingsir Wengi yang memuat karya-karya tahun 1975 hingga 2013.

Suharmono K. termasuk penyair yang memiliki respons yang tinggi terhadap berbagai hal di sekitarnya. Dia memiliki kepekaan yang baik sehingga momenmomen puitik dapat diciptakan sepanjang hidupnya. Unsur biografis puisinya sangat kuat, perjalanan hidupnya beserta orang-orang di sekitar, kelas sosial, serta relasi yang dibangun beserta pandangan hidup dapat terlacak. Puisi-puisinya sangat cocok untuk dibedah berdasarkan teori Strukturalisme Genetik ala Lucien Goldmann. 
Puisi-puisi Suharmono K. merupakan representasi budaya dan kehidupan Jawa yang khas, nadanya tenang dan gayeng, tidak meledak-ledak. Sirkulasi waktu yang membuat banyak hal berubah melahirkan romantika dan menjadi renungan penyairnya. Perubahan yang mau tak mau harus diterima melahirkan sikap sumeleh dan pasrah, tapi masih memiliki harapan untuk lebih baik. Pada tahap demikianlah momen religius muncul pada puisi-puisi Suharmono. Ada keteguhan yang harus tetap dipegang sambil menyeru agar hidup berjalan tidak keliru.

\section{SAMPAK PONORAGAN}

iki gendhing sampak ponoragan

katulis ing tengah ratri siji sura

sasi jawa sewu sangang atus telung puluh pitu

sumoroto sepi nyenyet

nalika bujang ganong anjir walik ing mega-mega

bantarangin direnggani lintang abyor ing tawang

iki sampak ponoragan

aja lali sembah lawung

awit isih ana langit sandhuwure langit ora suwung

menyang endi parane reriptamu sing jare adiluhung?

aja banjur dibuwang sebrung

kanthi pawadan kita mung satitah

kudune malah madhep mantep jroning manembah

iki sampak ponoragan

jaran kepang tetegar ing ara-ara

barongan lan dhadhak merak iker ing tengah samodra

wus daktlusuri kaprawirane warok suramenggala

yagene sipat iku saiki ilang musna, kabuncang angin prahara

ari remeng-remeng kasaput peteng lelimeng

iki sampak ponoragan

kelana sewandana lagi kiprahan

nalika warok-warok sesumbar kanthi blak-blak-an

ora ana tembung kang ngalik-alik kajaba thokleh

awit saben ucapan adhedhasar kasunyatan tanpa pamrih

kang diucapake dening paraga prasaja saka telenge ati kang putih

\section{Puisi Suparto Brata}

Puisi terakhir dalam Gurit Bandha Donya adalah karya Suparto Brata. Selama ini saya belum pernah membaca puisi atau guritan karya beliau. Dalam buku ini 
hanya ditampilkan sebuah puisi karyanya, itu pun hanya berupa satu kata yang diletakkan di tengah halaman : PLUNG! Saya yakin keikutsertaannya dipaksakan. Entah siapa yang memaksakan. Belum ada yang bisa dikedepankan, tidak sebanding dengan posisi Suparto Brata sebagai tokoh yang mapan dan produktif dalam dunia prosa.

Dari sisi orisinalitas, puisi PLUNG! di atas juga bukan barang baru. Akhudiat, dalam Buku Puisi Diat yang terbit stensilan tahun 1977 juga menulis puisi demikian. Akhudiat menulis puisi satu kata tersebut di tengah-tengah halaman, bedanya akhudiat menuliskannya demikian:

\section{((( plung )))}

Tentu saja baik dan buruknya puisi tidak semata-mata ditentukan oleh panjang atau pendeknya. Puisi adalah seni bahasa yang menyangkut bentuk dan isi yang terkandung. Pada aspek estetika bentuk kita tidak dapat menghindar dari jumlah dan kualitas kata yang disusun sedemikian rupa. Orisinalitas adalah kreteria paling utama yang harus diperhatikan dalam karya seni.

\section{SIMPULAN}

Kreativitas dan orisinalitas adalah menciptakan yang tidak ada menjadi ada. Perbedaan menjadi hal yang sangat penting. Dalam Gurit Bandha Donya para penyair telah menuangkan kesaksian dan perjalanan kreatifnya melalui pertarungan dua bahasa. Puisi yang tersaji adalah catatan anak zaman yang melahirkannya. Keberadaannya juga merupakan pertarungan dua dunia: antara harapan dan kenyataan, antara masa lalu dan masa kini, serta antara kreasi dan reproduksi.

Tampaknya puisi yang lebih awal ditulis adalah yang berbahasa Jawa. Puisi berbahasa Jawa umumnya lebih padat, idiomnya juga lebih mengena. Sementara yang berbahasa Indonesia lebih cair, struktur dan bentuk fisiknya lebih panjang, bahkan idiom atau pilihan katanya sering terkesan aneh karena penerjemahannya bertolak dari makna kata perkata, bukan makna struktural yang melekat di balik itu.

Judul buku kumpulan puisi Gurit Bandha Donya diterjemahkan menjadi Puisi Kekayaan Dunia mengalami pergeseran konotasi makna, dari negatif ke positif. Judul buku diambil dari puisi Aming Aminoedhin, yang karya-karya mudah dipahami dan cocok dibacakan di depan umum. Penerjemahan puisi-puisi Aming tidak banyak menimbulkan masalah karena sifat komunikasi terang benderang.

Penerjemahan puisi Djoko Prakosa ke bahasa Indonesia ada kecenderungan bentuknya menjadi lebih panjang, penyair sebagai penerjemah ingin lebih menjelaskan makna puisi terjemahannya sehingga menjadi prosais. Ini pula yang 
dilakukan Trinil dalam menerjemahkan puisinya dengan cara menambahkan keterangan dengan kata tertentu. Sebaliknya, pada terjemahan puisi Deny Tri Aryanti justru terjadi pengurangan konsep dengan hilangnya kata-kata tertentu yang fungsi dan maknanya sangat esensial.

Puisi-puisi Giryadi, yang secara umum menyiratkan makna kesepian dan kekecewaan yang disembunyikan, tidak banyak mengalami masalah dalam penerjemahannya. Puisi-puisi Widodo Basuki juga tidak mengalami masalah dalam penerjemahannya. Puisi Widodo Basuki cenderung mengarah ke perenungan spiritual yang kuat, dari mana dan akan ke mana hidup ini berjalan. Sementara itu puisi Suharmono K. memiliki akar kultural yang kuat secara genetic, penerjemahannya juga tidak banyak mengalami masalah. Sebuah puisi pendek karya Suparto Brata yang teridiri atas satu kata "PLUNG!" belum layak dikedepankan, bahkan kata tersebut pernah diproduk oleh Akhudiat.

\section{DAFTAR PUSTAKA}

Aminoedhin, Aming; dkk. (2014). Gurit Bandha Donya, Puisi Kekayaan Dunia. Surabaya:

Paguyuban Pengarang Sastra Jawa Surabaya.

Eco, Umberto. (2016). Teori Semiotika (Terjemahan Inyiak Ridwan Muzir). Bantul: Kreasi

Wacana.

Hogan, Patrick Colm. (2000). Philosophical Apparoaches to the Study of Literature. Florida:

University Press of Florida.

Luxemburg, Jan van; Mieke Bal; Willem G, Weststeijn. (1986), Pengantar Ilmu Sastra

Samsuri.1983. Analisis Bahasa. Jakarta: Erlangga.

Sayuti, Suminto, A. (2002).Berkenalan dengan Puisi. Yogyakarta: Gama Media.

Setiawan, Kodrat Eko Putro; Andayani; Retno Winarni. (2016). "Makna Puisi Ziaroh Karya dalam

F.Aziz Manna dan Relevansinya dalam Ajaran Islam: Kajian Semiotik”

http://www.syekhnurjati.ac.id/jurnal/index.php/jeill/article/downloadSuppFil e/1722/225.

(diakses 13 November 2021)

Skilleas, Martin. (2001).Philosophy and Literature An Introduction. Edinburg:

Edinburg

University Press.

Supardi, Moh. (2017). "Dinamika Penerjemahan Sastra: South of The Slot". dalam Buletin Al-Turas Mimbar Sejarah,Sastra,Budaya, dan Agama - Vol. XXIII No.2, Juli 
2017.

http://journal.uinjkt.ac.id/index.php/al-turats/article/download/5415/3923 (diakses 12

November 2021

Supriyanto, Henri. (1986). Pengantar Studi Teater. Surabaya: Kopma IKIP Surabaya.

Supriyanto, Henri. (1992). Lakon Ludruk Jawa Timur. Jakarta: Grasindo.

Supriyanto, Henricus. (2012). Postkolonial Pada Lakon Ludruk Jawa Timur. Malang:

Bayumedia Publishing

Teeuw,A.. (1983). Membaca dan Menilai Sastra. Jakarta: PT Gramedia. 